Paivio, A., Yuille, J. C., \& Madigan, S. A. (1968). Concreteness, imagery, and meaningfulness values for 925 nouns. Journal of Experimental Psychology Monographs, 76 (1, Pt. 2).

Rabinowitz, J. C., Ackerman, B. P., Craik, F. I. M., \& Hinchley, J. L. (1982). Aging and metamemory: The roles of relatedness and imagery. Journal of Gerontology, 37, 688-695.

RUNQUisT, W. N. (1983). Some effects of remembering on forgetting. Memory \& Cognition, 11, 641-650.

SALThouse, T. A. (1991). Theoretical perspectives on cognitive aging. Hillsdale, NJ: Erlbaum.

SALTHOUSE, T. A. (1992). Mechanisms of age-cognition relations in adulthood. Hillsdale, NJ: Erlbaum.

Salthouse, T. A., \& Dunlosky, J. (1995). Analyses of adult age differences in associative learning. Zeitschrift für Psychologie, 203, 351-360.

ShaW, R., \& CraIK, F. I. M. (1989). Age differences in predictions and performance on a cued recall task. Psychology \& Aging, 4, 131-135.
SPENCER, W. D., \& RAZ, N. (1995). Differential effects of aging on memory for context and content: A meta-analysis. Psychology \& Aging, 10, 527-539.

\section{NOTE}

1. Analysis of data in both experiments is based on standard errors of the means reported with each figure. To allow comparisons either between age groups or across trials, standard errors are reported both for the between-subjects variable of age group and for the within-subjects variable of trial (Loftus \& Masson, 1994). Differences declared as significant were also substantiated by inferential tests (e.g., analysis of variance and $t$ tests) in which $p<.05$.

(Manuscript received January 18, 1996; revision accepted for publication September 20, 1996.)

\title{
Workshop on Representation and Blindness San Marino, Republic of San Marino May 22-23, 1998
}

The workshop will include invited and other presentations by researchers in the field of touch, perception, and cognition, with special relevance to blindness. The meeting will be open to interested parties from a variety of disciplines within the sphere of perceptual and cognitive processes in blindness. We will consider abstracts for brief oral presentations and posters that involve theoretical and applied work. Send abstracts, if possible, by October 15, 1997.

San Marino is the capital of the Republic of San Marino, a small state located in central Italy. For further information, please contact the organizers of the workshop, by e-mail if possible: Cesare Cornoldi, Dipartimento di Psicologia Generale, Piazza Capitaniato 3, 35139 Padova, Italy (e-mail: cornold@psico.unipd.it) or Morton A. Heller, Psychology, Winston-Salem State University, Winston-Salem, NC 27110, U.S.A. (e-mail: mheller@ols.net). 